\title{
Infant Feeding Practices and Nutritional Status of Children of Less Than 1 Year
}

\author{
MUSTANSHIRAH LUBNA ${ }^{1}$, NAZMA BEGUM ${ }^{2}$, SOOFIAKHATOON ${ }^{3}$
}

\begin{abstract}
:
Objective(s): To determine infant feeding practices along with the nutritional status of under 1 year children.

Materials and Method: This descriptive type of cross sectional study was carried out in Department of Paediatrics of Shaheed Suhrawardy Medical College Hospital during the period from July to December 2012 on 52 admitted children of 29 days to 1 year of age.

Results: Exclusive breastfeeding was found in 19 (86.4\%) cases in under 6 months age group and $3(10.0 \%)$ cases in more than 6 months age group. Complementary feeding with breastfeeding was found in $76 \%$ of more than 6 months old infant. Majority patients in both groups received breastfeeding $>8$ times $/ 24$ hour. Ninety five percent infants of $\leq 6$ months of age who were on exclusive breastfeeding and eighty three percent infants of $>6$ months who were on breastfeeding plus complementary feeding were in normal nutritional status.
\end{abstract}

Conclusion: Exclusive breastfeeding in infants upto 6 months of age and breastfeeding with complimentary feeding in more than 6 months of age provided better nutritional status.

Keywords: Exclusive breast feeding, Supplementary feeding, Complementary feeding, nutritional status

\section{Introduction:}

Proper feeding practices during infancy are essential for attaining and maintaining proper nutrition, health and development of infant and children. ${ }^{1,2}$ Bangladesh has strong culture of breastfeeding but many aspects of infant and young child feeding are far from optimal. ${ }^{2}$ Infant should be breastfed within half an hour of birth, exclusively breastfed for the first six months of life and thereafter should receive nutritionally adequate and safe complementary foods while breastfeeding continues up to two years and beyond. ${ }^{3}$ In countries with a moderate or high infant mortality rate, artificially fed infants are at least 14 times more likely to die from diarrhea than breastfed children and four times more likely to die from pneumonia. Recent research has been shown that mortality in under five children can be reduced by $13 \%$ with optimal breastfeeding and a further $6 \%$ with optimal complimentary feeding ${ }^{4}$. In our country the initiation of breastfeeding is often delayed, with less than $42 \%$ within an hour and only $64 \%$ of infants are breastfed exclusively for 6 months. About $60 \%$ infants were given complementary feeding timely. ${ }^{4}$ Foods given beside breast milk after completion of 6 month is termed complementary feeding and any food given before six months of age with or without breast milk is called supplementary food. .Complementary foods given to infants and young children in Bangladesh are often nutritionally inadequate and unsafe, leading to malnutrition. Foods from animal sources such as fish, chicken, beef and egg are expensive and not commonly given to children. Only $22 \%$ of children aged $6-9$ months are given foods from animal sources. ${ }^{5}$ In Bangladesh almost one half $(48 \%)$ of children less than five years are underweight and $42 \%$ are stunted. ${ }^{6}$ Consequences of inappropriate feeding practices in early childhood are major obstacles to the government efforts towards sustainable socioeconomic development and poverty reduction. Correction of inappropriate feeding practices can also prevent malnutrition and consequences, including developmental delays, impaired educational ability, a lifetime of poor health, increase risk of chronic disease and early death ${ }^{2}$. So, the present study was done with the objectives to determine infant feeding

1. Medical Officer ( Paediatrics)

2. Assistant Professor (Paediatrics), Shaheed Suhrawardy Medical College

3. Professor, Centre for Women and Child Health 
practices along with the nutritional status of less than 1 year children admitted in Shaheed Suhrawardy Medical College and Hospital.

\section{Materials and methods:}

This descriptive type of cross sectional study was carried out in the department of Paediatrics of Shaheed Suhrawardy Medical College Hospital from July 2012 to December 2012. Children from 29 days to 1year of age admitted in Paediatrics ward during the study period were included in the study. History was taken about feeding status of the children. Then physical examination was done for weight, length, mid upper arm circumference (MUAC), skin changes (hypopigmentation, hyperpigmentation, ulcerarion, and dermatosis), edema and hair or eye changes (night blindness, conjunctival/ corneal xerosis, Bitot's spot, corneal ulceration). All these history and examination findings were recorded in a semi structured questionnaire. Nutritional status was calculated according to weight for length and length for age $\mathbf{Z}$ score. Then nutritional status was compared with feeding status. Data were analyzed using SPSS (Statistical Package for Social Sciences) version 16. Categorical data was presented as frequency, percentage and continuous variable was expressed as mean \pm SD (standard deviation). Written consent was taken from the parents after explaining the objectives of the study clearly. Confidentiality and privacy were maintained throughout the study.

\section{Results:}

A total of 52 patients were included in this study of which $22(42.3 \%)$ patients were upto 6 months of age and $30(57.69 \%)$ patients were between 6 months and 12 months. The mean age was found $6.26 \pm 3.17$ months with range from 1 month to 12 months(Table I). Among the 52 studied cases 32 (61.5\%) patient was male and female was $20(38.5 \%)$. Male female ratio was 1.6:1. Table II showed exclusive breastfeeding (EBF) was found in $19(86.4 \%)$ cases in under 6 months age group and $3(10.0 \%)$ cases in more than 6 months age group. Majority patients in both groups received breastfeeding $>8$ times $/ 24$ hour. (Table III). Table IV showed 19 (86.4\%) infants were given exclusive breast milk and $3(13.6 \%)$ infant given cow's milk in group $\leq 6$ months age group. Six (20\%) and $6(20 \%)$ child were given cows milk and khichuri in $>6$ months age infants respectively. In EBF group $18(94.7 \%)$ infants of $\leq 6$ months of age had normal weight or length $Z$ score and 1 (5.3\%) was mildly wasted whereas infants who were in breast feeding plus complementary feeding group 19(82.6\%) were in normal nutritional status in $>6$ months group (TableV). In EBF group 11 (61.1\%) infants of $\leq 6$ month had normal length for age $Z$ score. Whereas in infants older then 6 months age group 10 (43.5\%) had normal length for age $Z$ score and they received both breastfeeding and complementary feeding (Table VI). Majority of the patients (86.5\%) had 12.5 to 13.5 of mid upper arm circumference. Visible severe wasting was found in 8 (15.4\%), hair change in 13 (25.0\%), eye change in $1(1.9 \%)$, skin change in $6(11.5 \%)$ and oedema in $3(5.8 \%)$ patients (Table VII).

Table-I Distribution of infants by age $(n=52)$

\begin{tabular}{lcc}
\hline Age (Months) & Number of patients & Percentage \\
\hline $1-2$ & 4 & 7.69 \\
$3-4$ & 11 & 21.2 \\
$5-6$ & 7 & 13.4 \\
$7-8$ & 15 & 28.8 \\
$9-10$ & 9 & 17.3 \\
$>10$ & 6 & 11.5 \\
Mean \pm SD & $6.26 \pm 3.17$ & \\
Range(min - max) & $(1-12)$ & \\
\hline
\end{tabular}

Table-II

Distribution of infants by current feeding status ( $n=52)$

\begin{tabular}{|c|c|c|c|c|c|}
\hline \multirow[t]{3}{*}{ Feeding status } & \multicolumn{4}{|c|}{ Age (months) } & \multirow[b]{3}{*}{ Total } \\
\hline & \multicolumn{2}{|c|}{$\begin{array}{c}<6 \text { (Months) } \\
(\mathrm{n}=22)\end{array}$} & \multicolumn{2}{|c|}{$\begin{array}{c}>6 \text { (Months) } \\
(n=30)\end{array}$} & \\
\hline & $\mathrm{n}$ & $\%$ & $\bar{N}$ & $\%$ & \\
\hline Exclusive breastfeeding & 19 & 86.4 & 3 & 10.0 & 22 \\
\hline Only complementary feeding(CF) / supplementary feeding & 2 & 9.1 & 4 & 13.3 & 6 \\
\hline Breastfeeding+supplementary feeding /complementary feeding & 1 & 4.5 & 23 & 76.7 & 24 \\
\hline$\overline{\text { Total }}$ & 22 & & 30 & & 52 \\
\hline
\end{tabular}


Table-III

Distribution of infants by frequency of breastfeeding in 24 hours $(n=52)$

\begin{tabular}{|c|c|c|c|c|}
\hline \multicolumn{3}{|l|}{ Frequency of Breast Feeding in 24 hours } & \multicolumn{2}{|c|}{ Age (months) } \\
\hline & \multicolumn{2}{|c|}{$<6$ (Months) $(\mathrm{n}=22)$} & \multicolumn{2}{|c|}{ > 6 (Months) $(\mathrm{n}=30)$} \\
\hline & $\mathrm{n}$ & $\%$ & $\mathrm{n}$ & $\%$ \\
\hline$<8$ Times & 3 & 13.6 & 7 & 23.3 \\
\hline >8 Times & 19 & 86.4 & 23 & 76.7 \\
\hline
\end{tabular}

Table-IV

Distribution of infants by type of food given $(n=52)$

\begin{tabular}{lcccc}
\hline Type of food given in last 24 hrs & \multicolumn{2}{c}{$<$ month(n= 22) } & \multicolumn{2}{c}{$>6$ month(n=30) } \\
& $\mathrm{N}$ & 86.4 & 3 & $\%$ \\
\hline Exclusive Breast milk & 19 & 13.6 & 6 & 10.0 \\
Cow's milk & 3 & - & 6 & 20.0 \\
Khichuri & - & - & 3 & 20.0 \\
Muri & - & - & 3 & 10.0 \\
Rice & - & - & 3 & 10.0 \\
Egg & - & - & 3 & 10.0 \\
Dal & - & - & 2 & 10.0 \\
Formula milk & - & - & 1 & 6.7 \\
Fish & - & & 3.3 \\
\hline
\end{tabular}

Table-V

Distribution of Weight for Length Z score to infants by feeding status $(n=52)$

\begin{tabular}{|c|c|c|c|c|c|c|c|c|c|c|}
\hline \multirow[t]{2}{*}{ Feeding status } & \multicolumn{5}{|c|}{$\begin{array}{l}\text { Weight for Length Z score } \\
\quad<6 \text { months }(n=22)\end{array}$} & \multicolumn{5}{|c|}{$\begin{array}{c}\text { Weight for Length Z score } \\
>6 \text { months }(n=30)\end{array}$} \\
\hline & $\begin{array}{c}+2 \text { to }-1 \\
\mathrm{n}=20 \\
\text { No } \\
(\%)\end{array}$ & $\begin{array}{c}<-1 \text { to }-2 \\
n=2 \\
\text { No } \\
(\%)\end{array}$ & $\begin{array}{c}<-2 \text { to }-3 \\
n=0 \\
\text { No } \\
(\%)\end{array}$ & $\begin{array}{c}<-3 \\
\mathrm{n}=0 \\
\text { No } \\
(\%)\end{array}$ & $\begin{array}{c}\text { Total } \\
\mathrm{n}=22 \\
\text { No } \\
(\%)\end{array}$ & $\begin{array}{c}+2 \text { to }-1 \\
n=20 \\
\text { No } \\
(\%)\end{array}$ & $\begin{array}{c}<-1 \text { to }-2 \\
n=5 \\
\text { No } \\
(\%)\end{array}$ & $\begin{array}{c}<-2 \text { to }-3 \\
n=4 \\
\text { No } \\
(\%)\end{array}$ & $\begin{array}{c}<-3 \\
\mathrm{n}=1 \\
\text { No } \\
(\%)\end{array}$ & $\begin{array}{c}\text { Total } \\
\mathrm{n}=30 \\
\text { No } \\
(\%) \\
\end{array}$ \\
\hline $\begin{array}{l}\text { Exclusive } \\
\text { Breast } \\
\text { Feeding }\end{array}$ & $\begin{array}{c}18 \\
(94.7)\end{array}$ & $\begin{array}{c}1 \\
(5.3)\end{array}$ & 0 & 0 & $\begin{array}{c}19 \\
(100)\end{array}$ & $\begin{array}{c}1 \\
(33.3)\end{array}$ & $\begin{array}{c}1 \\
(33.3)\end{array}$ & 0 & $\begin{array}{c}1 \\
(33.3)\end{array}$ & $\begin{array}{c}3 \\
(100)\end{array}$ \\
\hline $\begin{array}{l}\text { Only } \\
\text { Supplementary/ } \\
\text { Complementary } \\
\text { Feeding }\end{array}$ & $\begin{array}{c}1 \\
(50)\end{array}$ & $\begin{array}{c}1 \\
(50)\end{array}$ & 0 & 0 & $\begin{array}{c}2 \\
(100)\end{array}$ & 0 & $\begin{array}{c}1 \\
(25)\end{array}$ & $\begin{array}{c}3 \\
(75)\end{array}$ & 0 & $\begin{array}{c}4 \\
(100)\end{array}$ \\
\hline $\begin{array}{l}\text { Breast } \\
\text { Feeding + }\end{array}$ & 1 & 0 & 0 & 0 & 1 & 19 & 3 & 1 & 0 & 23 \\
\hline $\begin{array}{l}\text { Complementary } \\
\text { Feeding }\end{array}$ & $(100)$ & & & & $(100)$ & $(82.6)$ & (13) & $(4.4)$ & & $(100)$ \\
\hline
\end{tabular}


Table-VI

Distribution of Length for Age Z score in infants by feeding status $(n=52)$

\begin{tabular}{|c|c|c|c|c|c|c|c|c|c|c|}
\hline \multirow[t]{2}{*}{ Feeding status } & \multicolumn{5}{|c|}{$\begin{array}{l}\text { Length for age } Z \text { score } \\
>6 \text { months }(n=22)\end{array}$} & \multicolumn{5}{|c|}{$\begin{array}{l}\text { Length for age } Z \text { score } \\
>6 \text { months }(n=30)\end{array}$} \\
\hline & $\begin{array}{c}+2 \text { to }-1 \\
n=11 \\
\text { No } \\
(\%)\end{array}$ & $\begin{array}{c}<-1 \text { to }-2 \\
n=9 \\
\text { No } \\
(\%)\end{array}$ & $\begin{array}{c}<-2 \text { to }-3 \\
n=1 \\
\text { No } \\
(\%)\end{array}$ & $\begin{array}{c}<-3 \\
n=1 \\
\text { No } \\
(\%)\end{array}$ & $\begin{array}{c}\text { Total } \\
n=22 \\
\text { No } \\
(\%)\end{array}$ & $\begin{array}{c}+2 \text { to }-1 \\
n=20 \\
\text { No } \\
(\%)\end{array}$ & $\begin{array}{c}<-1 \text { to }-2 \\
n=5 \\
\text { No } \\
(\%)\end{array}$ & $\begin{array}{c}<-2 \text { to }-3 \\
n=4 \\
\text { No } \\
(\%)\end{array}$ & $\begin{array}{c}<-3 \\
\mathrm{n}=1 \\
\text { No } \\
(\%)\end{array}$ & $\begin{array}{c}\text { Total } \\
n=30 \\
\text { No } \\
(\%)\end{array}$ \\
\hline $\begin{array}{l}\text { Exclusive } \\
\text { Breast } \\
\text { Feeding }\end{array}$ & $\begin{array}{c}11 \\
(58)\end{array}$ & $\begin{array}{c}7 \\
(37)\end{array}$ & 0 & $\begin{array}{c}1 \\
(5)\end{array}$ & $\begin{array}{c}19 \\
(100)\end{array}$ & 0 & $\begin{array}{c}3 \\
(100)\end{array}$ & 0 & 0 & $\begin{array}{c}3 \\
(100)\end{array}$ \\
\hline $\begin{array}{l}\text { Only } \\
\text { Supplementary/ } \\
\text { Complementary } \\
\text { Feeding }\end{array}$ & 0 & $\begin{array}{c}1 \\
(50)\end{array}$ & $\begin{array}{c}1 \\
(50)\end{array}$ & 0 & $\begin{array}{c}2 \\
(100)\end{array}$ & 0 & $\begin{array}{c}2 \\
(50)\end{array}$ & $\begin{array}{c}2 \\
(50)\end{array}$ & 0 & $\begin{array}{c}4 \\
(100)\end{array}$ \\
\hline $\begin{array}{l}\text { Breast } \\
\text { Feeding }+ \\
\text { Complementary }\end{array}$ & 0 & $\begin{array}{r}1 \\
(100) \\
\end{array}$ & 0 & 0 & $\begin{array}{c}1 \\
(100) \\
\end{array}$ & $\begin{array}{c}10 \\
(43.5) \\
\end{array}$ & $\begin{array}{r}12 \\
(52) \\
\end{array}$ & 0 & $\begin{array}{c}1 \\
(4.3) \\
\end{array}$ & $\begin{array}{r}23 \\
(100) \\
\end{array}$ \\
\hline
\end{tabular}

Feeding

Table-VII

Distribution of infants by other examination $(n=52)$

\begin{tabular}{lll}
\hline Variable & Number & Percentage \\
\hline
\end{tabular}

Mid Upper Arm Circumferences

$\begin{array}{lcc}12.5-13.5 & 45 & 86.5 \\ <12.5 & 7 & 13.4\end{array}$

Visible severe wasting

$\begin{array}{lcr}\text { Yes } & 8 & 15.4\end{array}$

Hair change

Yes

$13 \quad 25$

No

$39 \quad 75$

Other changes

Eye change (night blindness,

11.9

conjunctival/ corneal xerosis,

Bitot's spot, corneal ulceration)

$\begin{array}{lll}\text { Skin change ( hypo/hyperpigmentation, } & 6 & 11.5\end{array}$

Oedema

3

5.8

\section{Discussion}

In this study it was observed that most $(25.0 \%)$ of the patients aged belonged to 7-8 months and their mean age was found $6.26 \pm 3.17$ months with range from 1 month to 12 months. Khatun and Siddiqua studied infant feeding practices and found $41.3 \%$ of the studied patients were in 9 months age, which is comparable with the current study ${ }^{7}$. On the other hand, Khan et al has observed higher mean age range in their study, which belonged to 12 to 23 months $^{8}$. In another study the average age was found $14.7 \pm 6.0$ months, which is also higher than the current study ${ }^{9}$. It was observed in this study that male $(61.5 \%)$ was predominant, where male to female ratio was 1.6: 1. Similar observations were also made by Khan et al, Ulak et al, Sarid and Shraga and Mushaphi et al. ${ }^{8,9,10,11}$ 
In this study exclusive breast feeding was found in $19(86.4 \%)$ cases under 6 months age group and in 3 $(10.0 \%)$ cases in more than 6 months age group. The national figure of EBF is $64 \%$ whereas in this study EBF rate was $86.4 \%$, which is higher than national data. The cause may be that the Shaheed Suhrawardy Medical College and Hospital is a baby friendly hospital.

According to weight for length Z score (WLZ), 18 $(94.7 \%)$ cases were normal, $1(5.3 \%)$ case was mildly wasted in $\leq 6$ months age group. Whereas in more than 6 months to 1 year age group, according to WLZ, $20(66.7 \%)$ cases were well nourished, $5(16.71 \%)$ were mildly wasted, $4(13.5 \%)$ cases were moderately wasted and 1 was severely wasted. Among the 20 well nourished cases 19 infants received both breast feeding and complementary feeding. Mushaphi et al done a study on infants age belonged to 1 to 12 months selected from five primary healthcare clinics in South Africa. found $75.7 \%$ well nourished and $7 \%$ wasted infants respectively in their study. ${ }^{11}$

In this study, according to length for age $Z$ score (LAZ) in $\leq 6$ month age group, $11(58 \%)$ cases were well nourished, 7 (37\%) cases were mildly stunted and $1(5 \%)$ case was severely stunted who were on EBF. In this age group all cases who were not on EBF were found mild to moderately stunted. In $>6$ months age group according to $L A Z, 43.5 \%$ cases and $4.3 \%$ cases were found mildly and severely stunted respectively who were on breast feeding with complementary feeding. Whereas all cases in this age group who were on only breast feeding or complementary feeding were found mild to moderately stunted. Basnet et al. found $51.6 \%$ of infant were stunted in urban area in Nepal who were not on EBF. ${ }^{12}$ Whereas Mushaphi et al. studied nutritional status of infants in the Vhembe District Limpopo Province found low LAZ in $18.9 \%$ cases, $78.4 \%$ normal $L A Z$ and $2.7 \%$ high LAZ in their study. ${ }^{11}$ Among the 52 infants in the present study, 3 (5.8\%) were severely malnourished. Among them 2 cases were under 6 months and another one was more than 6 months. Though 2 infants below 6 months were exclusively breast fed but they were suffering from severe malnutrition (FTT) because of their chronic disease (congenital heart disease) for which they were admitted in the hospital.

\section{Conclusion:}

According to findings of the present study it can be concluded that exclusive breastfeeding was optimum upto 6 months of age. Exclusive breastfeeding provided better weight for length and length for age even in sick admitted infant of upto 6 months of age. But for infants more than 6 months neither exclusive breast feeding nor complementary feeding alone was appropriate for growth and development. Rather breastfeeding with complementary feeding provided better weight for length and length for age for more than 6 months of age infant. This study indicates the necessity of multicentre study of larger sample size.

\section{References:}

1. Saha KK., Frongillo EA., Alam DS., Arifeen SE., Persson LA., Rasmussen, KZM. Appropriate infant feeding practices result in better growth of infant and young children in rural Bangladesh. American Clinical Nutrition 2008 ; 87(6): 1852-59.

2. Ministry of Health and Family. National strategy for infant and young child (2007).

3. WHO.Global strategy for Infant and Young Child feeding status in Bangladesh. Publication of $8^{\text {th }}$ Commonwealth Congress on diarrhea and malnutrition. Unicef 2000.

5. Alam DS., Raaij JMA., Hautvast JGAJ., Yunus M., Fuchs GJ. Infant-feeding Practices, Morbidity, and Growth during the First Six Months of Life in Rural Bangladesh.ICDDRB Publications of annual scientific conference2000; 39.

6. Hannan A., Hassan MQ, Rahman AKMF., Rahman A., Talukder MQK. Infant-feeding Practices from Birth to Two Years of Age and Nutritional Status of Children and Mothers in Bangladesh. ICDDR,B 10th ASCO N 2002; Abstract no. 133.

7. Khatun M., Siddiqua SA. Infant feeding practices among mothers of high and low socio-economic group in selected areas of Dhaka city. Journal of Shaheed Suhrawardy Medical College 2010; 2(1): 17-20. 
8. Khan MI., Hoque MA., Mollah AH., Islam MN., Latif SA., Hossain MA. Feeding practices and nutritional status of children under two years of age. Mymensingh Med J 2011; 20(4): 558-65.

9. Ulak M., Chandyol RK., Mellander L., Shrestha PS., Strand TA.. Infant feeding practices in Bhaktapur, Nepal: a cross-sectional, health facility based survey. International Breastfeeding Journal 2012; 7(1): 1-8.

10. Sarid O., Shraga Y. Infant sleeping and feeding patterning: A cultural perspective on maternal practices. Journal of Nursing Education and Practice 2013; 3(6): 118-24.

11. Mushaphi LF., Mbhenyane XG.., Khoza LB., Amey AKA.. Infant-feeding practices of mothers and the nutritional status of infants in the Vhembe District of Limpopo Province. S Afr J Clin Nutr 2008; 21(2): 36-41.

12. Basnet S, Gauchan E, Malla K, Malla T, Koirala D., Rao KS., et al. Infant Feeding Practices in Kaski District. Nepal Paediatr Soc 2012; 32(1): 23-27 